\title{
The Implications of Consumer Protection Legislation for Hotels and Guests in South Africa
}

\author{
Raeesah Mohamed, Karunanidhi Reddy*, P.M. Naidoo \\ Durban University of Technology, South Africa \\ raeesah_786@yahoo.co,reddyk@dut.ac.za, jaya@dut.ac.za
}

\begin{abstract}
During the apartheid era, consumers in South Africa, based on their race and ethnicity, were restricted when concluding contracts, as there was no open market trade. As consumers, hotel guests could also be victims of unfair business practices. Hotels use standard form contracts that may include unfair terms that favour the business and which are over-protective of business interests. A significant percentage of the population have low literacy levels, which severely disadvantage them when it comes to understanding the content and consequence of contracts. The Consumer Protection Act (CPA) introduces wide-ranging legal measures to protect consumers, including hotel guests, from exploitation and abuse in the marketplace and sets out comprehensive obligations for hotels. This article provides a descriptive critique based on literature and describes the challenges faced by hotel guests and discusses the implications of the Act for hotels and guests. It concludes that not only does the CPA advocate ethical business practices that are mandatory for hotels, but it also introduces a range of rights and protection for guests as consumers. The CPA has introduced a shift in contract law from a standpoint which allowed the parties the freedom to choose the content of the contract to one where fairness and transparency is imperative, as protection in terms of legislation compensates for the weaker bargaining position of the consumer.
\end{abstract}

Keywords: Consumer protection; consumer rights; hotels; guests; contract

\section{Introduction}

In a free market economy, interference by the state should ideally be minimal as there is a risk that consumer protection measures may be over-protective and could restrict the consumer's right to choose (Woker, 2010: 218). Throughout the world, there are businesses that are intent on exploiting consumers in some way. Over the years, there have been calls for South Africa to follow in the footsteps of most first-world countries and introduce comprehensive legal measures to protect consumers from possible exploitation and abusive practices by suppliers (Sharrock, 2011:570). Hawthorne (2012: 345-6) maintains that contract law in South Africa oscillates between the freedom-oriented approach and the fairness-based approach. In terms of the freedom-oriented approach, party autonomy means that the parties to the contract are free to determine the content of the contract; there is minimal state supervision; and legislative measures may be limited to addressing the infringement of rights after the fact. The fairness-based approach represents "a progressive form of law" which affects procedural and substantive fairness. Hawthorne (2012: 346) further argues that the law of contract was very slow to transform to meet the new constitutional imperatives after the dawn of democracy in South Africa, and that the consumer protection legislation has brought a fairness-based approach to the law of contract. The analysis of the different provisions of the Consumer Protection Act 68 of 2008 (RSA, 2008) (referred to as "the Act" or CPA) bears in mind these different paradigms.

Woker (2010: 230-1) provides the following reasons why consumer protection legislation was needed in South Africa: (a) most of the consumer law prior to the CPA was fragmented and outdated; (b) consumers were not afforded the benefit of certain consumer protection principles which were recognised internationally, including the right to transparency and fair advertising practices; (c) unfair practices were rife and consumers found themselves in an "unequal bargaining position"; (d) consumers lacked the requisite knowledge of consumer rights and were convinced to conclude contracts with terms that protected the suppliers' interests; and (e) consumers lacked the resources to take a matter to court, considering that litigation is relatively expensive and consumer-related disputes usually pertain to claims that are relatively small. During the apartheid era, consumers from certain racial or ethnic groups were restricted or prevented from concluding contracts, as open market trade did not exist. These consumers did not have the freedom of contract because of discriminatory legislation that existed. Furthermore, consumers from historically disadvantaged groups experienced challenges with regard to access to goods and services (Reddy, 2012: 586). Before the CPA was introduced in South Africa, a national consumer survey showed that consumers, mainly those from underprivileged communities and rural areas, were ignorant about their rights. According 
to Booysen (2011), such a lack of knowledge has led to consumers suffering a host of abuses, including misleading advertising, bait advertising, suppliers failing to honour guarantees, non-disclosure, contract terms that were unfair and unsatisfactory product quality. Until recently, South Africa did not have a wideranging approach to consumer protection. Instead, a number of isolated provisions were present in various pieces of legislation that covered different aspects of consumer protection.

The CPA came into effect on 1 April 2011. In general terms, the Act proposes to bring about fairness and transparency in consumer-related transactions and encourage good business practices on the part of suppliers of goods or services (Gordon-Davis \& Cumberlege, 2013: 115). Hawthorne (2012: 353-354) maintains that the CPA aims to "promote and advance the social and economic welfare of consumers in South Africa" and that the following means are proposed by the Act to achieve such purpose: (a) creating a legal framework that will ensure a fair, accessible and responsible consumer market; (b) assisting disadvantaged and vulnerable consumers; (c) promoting fair business practices and access to goods and services; (d) protecting consumers from unfair business practices; (e) providing for consumer education; and (f) providing an accessible and efficient system of dispute resolution and redress for consumers. In the services sector, the hospitality and tourism industry is often identified as a prominent industry worldwide "in terms of generation of income and employment" (Okumus, 2010: 56). The hospitality industry includes hotels, bed and breakfast establishments, lodges, resorts and backpacking. For the purpose of this article, the focus will be explicitly on the hotel sector.

Since low literacy levels are a challenge for a significant number of consumers in the country, such consumers are seriously disadvantaged as far as comprehending the content and effect of business contracts are concerned (Reddy, 2012: 584). Standard form contracts contain terms that are set by the supplier, including hotels, and which have not been negotiated with the consumer. Such terms generally favour business and are over-protective of business interests, and they are included mainly to minimize the risk of the organisation and to avoid liability as far as possible (Sharrock, 2010: 296; Reddy \& Rampersad, 2012: 7407). It is common practice that when guests check into a hotel, they are presented with a pre-printed contract which they are required to sign before the room key is handed over. Negotiation on an equal footing does not take place. Sharrock (2010: 296) asserts that business organisations generally assume a "take-it-or-leave-it" stance if a customer asks for an amendment to the standard terms. Such standard form contracts may also contain terms that are unfair to the consumer (Reddy, 2012: 584). This article conveys a descriptive critique, based on bibliographic research, on the implications of the CPA for hotels and guests in South Africa. This article firstly explores the challenges faced by guests; the need for; and the application of, the CPA. Secondly, the respective provisions of the Act are explored and the broad implications of such wide-ranging provisions for hotels and guests are examined.

\section{Challenges faced by guests}

The challenges that guests face on a daily basis relate generally to terms and agreements by hotels; payment issues; refund and cancellations; and unfair practices by hotels. This section examines the challenges faced by hotel guests insofar as they may relate to consumer protection.

Terms and Agreements by Hotels: Emanuel (2010) defines a "contract" as an agreement, which is enforced by law (Emanuel, 2010: 1). As with every contract, the hotel-guest agreement also contains terms and conditions which a guest agrees to upon signing the contract. As mentioned earlier, the low literacy levels of consumers seriously hamper them when it comes to understanding contractual terms and the implications they have (Reddy \&Rampersad, 2012:7407). This has serious consequences for the unsuspecting consumer. A contract is binding by law and if a guest does not read the terms and conditions, they could still be bound by such terms and incur liability. Guth (2011: 1) correctly points out that the fine print and legalese of a hotel contract is not nearly as interesting for the guest until challenges arise. Even if individuals do not read the terms and the agreement, they should at least be given the opportunity to do so (Ben-Shahar, 2009: 2). Often hotels have a set check-in time and a queue may form. Guests may therefore be under pressure to sign hastily, without properly reading the terms set out in the agreement. Guests would therefore need to be protected in such cases. 
Growth in terms of the proportion of bookings that are made online through the internet, has had a significant impact on both "distribution channels and profitability" in the hotel industry (Carvell \& Quan, 2008: 162). According to Wilson (2007: 361), when accommodation is reserved through the hotel website, the "browse wrap" approach is used (as opposed to the click wrap agreement), where the terms and conditions applicable are available on the website but the reservation for accommodation can be completed without the guest's express consent to such terms. The terms and conditions generally relate to jurisdiction or the authorization of arbitration in the event of disagreements. It is therefore in the hotel's interest to show that prospective guests have read and have agreed to such terms and conditions (Wilson, 2007: 361). Hence, hotels could face consumer protection issues where the hotel has not made the guest aware of such terms and conditions.

Payment, refunds and cancellations: One facet of performance in terms of the contract is payment (Jennings, 2012: 429). Although payments and terms for payment are generally relatively straightforward, in the hospitality industry, agreements regarding payment terms can sometimes be quite complex (Barth, 2006: 41). For instance, where the payment policy of the hotel imposes unnecessary liability on a guest and requires payment in excess of the charge for accommodation and other services utilized, such term will not be a fair term. According to Barth (2006: 42), the contract needs to be clear about the required deposit, interest rates on the outstanding balances, due dates for payment, and penalties applicable to late payments. Further, charges for late checkout, cancellations, no-shows and breakages must be clearly spelt out. If these terms have not been specified, or if the terms are ambiguous, this could present challenges. In addition, it should be clear whether the hotel or restaurant has included the service charge in the price of the meal, or if it is left to the discretion of the customer (Davis, Lockwood, Alcott \& Pantelidis, 2012: 49). There is clearly a need for hotels to represent fair and ethical business practices.

A guest may claim for a refund of payment usually where the guest has not received the service (for instance, on collation) or when sub-standard service is rendered. Such refunds can take the form of money, credit or vouchers (Gough, Gough, \&du Toit, 2008: 165). Like many hotels internationally, the reservations policies of large hotel chains in South Africa, may require a non-refundable pre-payment for certain rates, in order to confirm a reservation. Alternatively, confirmed reservations may be subject to a hundred percent cancellation fee, if they are modified or cancelled. Hence, in terms of such policies, monies paid for pre-booked hotel rooms are non-refundable. Hotels may adopt such a policy to protect themselves against the loss of business, particularly in the case of a no-show, cancellation or amendment, especially since the reservation of hotel rooms are an extremely perishable commodity and "unsold rooms" for the day are a loss incurred, as services cannot be stored. Hotels may promote discounted prices to prospective guests seeking "special deals" while simultaneously adding cancellation policies as hidden traps that increase the cost of accommodation for unsuspecting customers. Generally, the closer the cancellation is to the date of the intended stay, the more difficult it is for guests to receive a full refund (Chen, Shwartz \& Vargas, 2011:129). Cancellation is generally permitted. However, the guest is liable for a higher penalty closer to the date of arrival (Zakhary, Atiya, ElShishiny \& Gayar, 2011: 349). Some hotels may impose a cancellation fee and rely on a "no full refund" policy for services booked in advance. This is similar to asking the buyer to pay for reserved goods that are not then required. The move towards more stringent cancellation policies (which are less protective of the consumers right to a refund) by hotels presents further challenges for the guest (Chen, Shwartz \& Vargas, 2011:129).

Unfair Practices by Hotels: Hotels may be guilty of certain unfair practices, such as overbooking, where they confirm a greater number of rooms than the hotel's available capacity on the assumption that some customers will either not check-in, or that they may cancel or amend their bookings at the last minute, or even leave the hotel earlier than intended (Ivanov, 2014: 115). Although the intention on the part of hotels is not to overbook to the extent that customers are denied service, some customers may be denied accommodation if the number of guests who cancel or fail to check-in is lower than expected (Noone \& Lee, 2011: 334). Although overbooking is a common practice amongst hotels, recent studies have shown that overbooking has a potentially negative impact on guests (Chen, Shwartz \& Vargas, 2011: 130). In some cases, the guests may be referred to another hotel or they could be stranded due to overbooking.

Discrimination by Hotels: During the apartheid era, unfair discrimination was rife in almost every walk of life in South Africa. Not only was there discrimination imposed by the government, but apartheid supported, encouraged and even demanded unfair discrimination by individuals and businesses, mainly against Black 
people. There were glaring differences in the quality of goods and services that were offered to different groups of customers. In the retail sector, for instance, most chain stores did not even service most historically disadvantaged areas. In addition, suppliers did not consider people from such areas as customers. Generally, Black people were barred from shops and business, and instead, separate and inferior facilities were made available (Brink v Kitshoff, 1996: 768). Likewise, hotels refused admission to their facilities/services/accommodation on the basis of race or ethnicity, as in the case of the Silver Club Case (Lane, 2005: 22-23) or inferior accommodation and services were made available to Black customers although they were required to pay the same rates (Reddy, 2006: 785-786). However, discriminatory practices by hotels may not be just on grounds of race and could include:

- The problems faced by people with disabilities in finding accessible tourist accommodation (Darcy, 2010: 816). Marumoagae (2012: 345) maintains that not much has been done to address disability discrimination. Hotels do not recognise disability as a market and, hence do not promote the rooms in a way that could assist people with disabilities in making an informed choice regarding accommodation (Darcy, 2010: 816);

- Failing to provide for the needs of people from different cultural or religious backgrounds may amount to discrimination. Food and beverage consumption restrictions for different religious groups would be one example (Ruzevicius, 2012: 761). For instance, Hindus may not eat beef (Yu, 2012: 52), while Muslims want to be sure that their food conforms to Halaal requirements and Jewish guests will want to ensure that their food meets kosher standards (Ruzevicius, 2012: 761); and

- Price discrimination refers to the situation where a hotel charges its customer different prices for the same services (Ivanov, 2014: 101). Hotels implement price discrimination by using various rate restrictions to segment consumers into different groups, and different prices may be applicable to each group depending on the time or day of the week, refund-ability, and advanced purchase requirements (Guillet, Lui \& Law, 2014: 952). Bearing in mind that it would cost the hotel the same amount to provide a meal to a pensioner as compared to a regular customer, guests who have to pay more may feel that they have been unfairly discriminated against by the differentiation in price (Layton, Robinson \& Tucker, 2012:198).

Hence, there is clearly a need to protect guests from the various forms of unfair discrimination in the hotel industry.

Unwanted direct marketing by hotels: Direct marketing is where the marketer communicates directly with the consumer either by approaching him/her "in person, or by mail or electronic communication", for the purpose of promoting any goods or services (Section 1 of CPA). According to Hamann \&Papadopoulos (2014: 45) electronic communication to consumers may take the form of mobile cellular text and video messaging (SMS or MMS); mobile device applications (Apps.); email marketing and search engine optimization. Further, it could also take the form of social media marketing; banner advertising using mobile or internet (which include a static banner advertising, pop-up adverts and interactive advertising that appears alongside or over the website material) and voicemail marketing. Direct marketing does have a role to play in the economy and helps to match the supply of a service or product with the requisite consumer, thereby facilitating the conclusion of the transaction, which may be beneficial to both supplier and consumer (Hamman and Papadopoulos, 2014: 47). These means of marketing are vital for hotels to communicate promotional material to potential guests. Yet, consumers may be flooded by direct marketing from suppliers of all types of goods and services. Hotels too may be guilty of sending a flood of promotional material to guests and potential guests, as in the case of Spam mail (unsolicited electronic messages) where mail or copies of the mail are sent to a large number of recipients (Geissler, 2004). Advances in technology allow hotels to contact potential guests at any time, day or night, via email, SMS and telephone calls (Gladwin \& Civin, 2014: 13). Therefore, there is a need to protect such guests from unwanted direct marketing and marketing of such material by electronic means at all hours of the day or during weekends and holidays when the recipient may not want to receive such material.

\section{The Consumer Protection Act 68 of 2008}

According to Sharrock (2011: 571), the CPA prohibits or regulates marketing and business practices used by suppliers in transacting with consumers and it affords consumers certain rights, as well as remedies and 
options for legal redress, which did not exist under common law. In addition, the Act promotes fairness, openness and good business practices by suppliers of goods and services. This section sets out the purpose and application of the Act, as well as the provisions of the Act insofar as they may affect hotels.

The purpose of the Consumer Protection Act and its application to hotels: The scope of the CPA is wide as it applies to any goods or services promoted or supplied in South Africa (Marus, 2011: 36). The Act defines "service" to include the provision of accommodation (Section 1). Hence, the CPA would be applicable to business transactions in the hotel industry (Section 1). The Act also defines the term "supplier" to mean any person who markets goods and services, whether for profit or otherwise (Section 5 (8)(b)). Hotels would therefore qualify as suppliers in terms of the Act since they provide services. Such services consist of accommodation and the use of facilities (e.g. swimming pools, sporting and recreational facilities) as well as banqueting. However, a guest's hotel experience is not limited to the provision of services. Although a hotel guest is not viewed as the buyer of goods in the conventional sense, the definition of "goods" in the CPA is wide enough to apply to hotel and guest transactions. The definition of "goods" (Section1) includes"(a) anything marketed for human consumption" (which includes meals provided in a restaurant or ordered through room service, as well as drinks from the bar);"(b) any tangible object not otherwise contemplated in (a) above" (which may include hotel branded memorabilia available at the in-house curio shop); and "(c) data, software, code or other intangible product in written or encoded medium, or licence to use any such intangible product" (which may include digital information and computer access for guests at the business centre in a hotel, including internet access).

Hotel guests as customers/consumers: In the context of the hotel industry, the following persons would qualify as "consumers" in terms of the definition in Section 1 of the Act: (a) the person to whom the goods and services have been marketed (such as a prospective guest); (b) the person who concludes a transaction with a supplier (which may be a guest or third person concluding such a contract); and (c) a user of the particular goods or the person who receives the services, irrespective of whether they were a party to the transaction (such as a family member of the person concluding the transaction). When parties come to an agreement, it implies the existence of a contractual relationship creating rights and duties for them (Newman, 2010: 735). Consequently, the rights and duties of hotels and guests would be regulated by the contract governing such transaction and the CPA supplements the guest's rights in terms of such a contract. In addition, since even persons to whom services are marketed are included under the definition of the consumer, as mentioned above, potential guests would have rights under the CPA even before the hotel concludes a valid agreement with them. Hence, the rights provided for go beyond the contractual rights normally limited to the formal agreement concluded on check-in at the hotel. Based on the definitions outlined by the CPA, it is evident that a hotel guest is a consumer and the provisions of the CPA would definitely apply to a hotel-guest transaction, creating rights and duties for both parties.

\section{The Implications of the Consumer Protection Act for Hotels}

Chapter 2 of the CPA sets out nine fundamental consumer rights: the right to equality; the right to privacy; the right to choose; the right to disclosure and information; the right to fair and responsible marketing; the right to fair and honest dealing, the right to fair; just and reasonable terms and conditions; the right to fair value, good quality and safety; and the right to hold the supplier accountable. This section examines each of these rights insofar as they may affect the hotel industry. In an analysis of the fundamental consumer rights in the CPA, Hawthorne (2012: 356-68) distinguishes between those provisions that contribute to procedural fairness (which "sets the scene for the conclusion of the contract in circumstances that are fair") on the one hand, and substantive fairness (fairness or unfairness of the terms) on the other.

The right to equality in the consumer market: A serious problem which stemmed from apartheid and which existed prior to the implementation of the CPA was discrimination. Section 8 of the CPA relates to the duty of the supplier not to discriminate against any person. The South African Constitution (RSA, 1996) articulates that discrimination is unfair if it is on the grounds of race, sex, culture, religion, gender, social origin, age, disability, pregnancy, conscience, marital status, language and birth. Hotels may therefore not differentiate between guests in a manner that amounts to unfair discrimination. Hotels may not unfairly exclude any person from access to goods and services (such as the opportunity to take up accommodation at the hotel, or 
dining at the hotel's restaurant) or give any person/s exclusive access (Section 8(1) (a)). Section 8(2) of the CPA clearly states that a supplier must not unfairly discriminate against any person by treating such person differently from others. The Act explicitly mentions certain instances of discrimination that are prohibited. A supplier (i.e. the hotel) may not treat any person differently from any other when assessing the ability of a consumer to pay the cost of the agreement; deciding whether or not to enter into a transaction or agreement (for example if there is room availability in a hotel, the front desk personnel cannot just arbitrarily decide if a particular consumer should get it or not); or supplying different quality of goods or services to different groups of consumers. Where different terms and conditions are offered to different consumers (such as frequent guests are not required to pay deposits while regular guests must do so); and where certain communities and market segments are targeted, such conduct may also be regarded as discriminatory.

Differentiation is allowed as long as it amounts to fair discrimination, for instance, preferential treatment for loyalty programme guests as opposed to regular hotel guests may be permissible if it based on rational grounds. The CPA makes exceptions for reasonable grounds for differential treatment, which arises from the need to protect a particular group of consumers, such as not allowing the sale of alcohol or tobacco products to children under the age of eighteen, and instances where suppliers provide separate gender facilities (Gordon-Davis \& Cumberlege, 2013: 120). If a guest feels that the hotel has unfairly discriminated against him/her, then such person may seek recourse with the Equality Court or file a complaint with the Commissioner (Section 10 (1)). According to Section 10(2), discrimination is unfair if the hotel has treated a guest in a manner that amounts to differential treatment based on a prohibited ground (such as race, gender or disability) and the hotel cannot provide a reasonable or justifiable explanation as to why such person was treated differently. The Act aims to protect the interests of all consumers, including foreign consumers, against unfair discrimination (Reddy, 2012: 592). According to Tait and Tait (2010: 444) where foreign tourists are required to pay a higher price for a hotel's service than South Africans, and the difference in price is based purely on the ground of citizenship, it would violate the CPA, the Promotion of Equality Act 4 of 2000, as well as the provisions of the South African Constitution relating to unfair discrimination.

The right to privacy and restrictions on direct marketing: The right to privacy in terms of the CPA arises from Section 14 of the South African Constitution (Jacobs, Stoop \&van Niekerk, 2010: 320). This right makes provision for, amongst others, the right of the consumer to restrict unwanted direct marketing. Since hotels may engage in direct marketing in order to attract business, these provisions have implications for both hotels and guests. Sections 11 and 12 deal with the consumer's right to privacy and restricts unwanted direct marketing, i.e. either where the supplier approaches the consumer directly or by mail or electronic communication for the purpose of promoting any goods or services (Section 11; Hamaan and Papadopoules, 2014: 44). These provisions apply to marketing by hotels as well. The consumer has the right to restrict unwanted direct marketing and has the option to refuse such direct marketing or request that it be discontinued. The consumer may also pre-emptively block such marketing (Havenga, 2010: 488).

Advances in technology allow consumers to be contacted anytime, day or night, via email, SMS and telephone calls (Gladwin \& Civin, 2014: 13). To protect the guest's right to privacy, Section12 prohibits direct marketing at specified times. A hotel may therefore not engage in any direct marketing to a consumer at home on Sundays or public holidays or on Saturdays before $09 \mathrm{~h} 00$ and after $13 \mathrm{~h} 00$. On other days, they may not engage in such marketing before $08 \mathrm{~h} 00$ or after $20 \mathrm{~h} 00$. The Act permits direct marketing during these times only if the consumer specifically agrees to it in writing. Hotels therefore have to be cautious not to infringe a guest's right to privacy by sending direct marketing where such person has explicitly restricted unwanted direct marketing. They should also avoid sending direct marketing at prohibited times.

The right to choose: This section focuses on the guest's right to choose, including the right to select suppliers; the right to cancel a contract; as well as the right to choose and examine goods. According to Section 13, a supplier may not coerce consumers into (a) buying additional products from the same supplier; (b) entering into additional contracts with the same supplier or a particular third party; and (c) agreeing to buy goods or receive services from a third party. An example of such conduct in the accommodation sector is offering guests a free weekend on condition that they purchase a timeshare unit (Gordon-Davis \& Cumberlege, 2013: 121). 
The consumer's right to cancel: Direct marketing by hotels can result in guests being bound by a contract that they have not carefully considered. Section16 of the CPA relates to the consumer's right to a "cooling-off" period where such person concludes a contract with a hotel arising from direct marketing. It is likely that in such instances, the guest may not have had sufficient time to consider the consequences of such a contract or its terms. Section 16 protects guests by providing that they will have 5 days to reconsider the agreement and cancel if they choose to. According to Gordon-Davis and Cumberlege (2013: 121), this provision will have an impact on sales agreements in respect of new or potential timeshare or sectional title sales that result from direct marketing in the hotel industry. The CPA obliges the supplier to refund payments received within 15 business days of receiving the notice of cancellation (Section 16(4) (a)). Section 17 entitles the consumer to cancel an advance booking, reservation or order. However, in such case, the supplier may levy a reasonable charge for the cancellation (Section 17(3)). Section 18 relates to the consumer's right to choose or examine goods. Where the guest purchases goods purely based on a description given by the hotel, the goods delivered to the guest must correspond to what any other guest would have been entitled to expect. Hotels may use brochures, websites or pictures of menu items as part of their marketing strategy and this may create an expectation on the part of guests (Gordon-Davis \& Cumberlege, 2013: 121). Hotels must therefore ensure that the description provided in marketing material correlates with the product or service, which any other guest would expect.

The consumer's right in the event of overbooking: Overbooking is common practice in hotels and is generally followed to make up for last minute cancellations or no-shows. However, according to Section 19(6), if a hotel guest has pre-booked accommodation and upon checking-in finds out that there are no rooms available, the guest can accept an alternate location, date and time; or require the accommodation as agreed upon; or cancel the agreement without penalty. It is also imperative for hotels to ensure that guests receive the type of accommodation agreed to and in the case of overbooking the guest is not forced to accept accommodation which is inferior to/different from the one requested (Section 21(1)(e)). Section 47 deals with over-selling and over-booking and undoubtedly affects the hotel sector. If the hotel agrees to supply certain goods or services and fails to because it runs out of such stock (such as beverages or menu items) or is unable to supply such service (for instance, in the case of overbooking of rooms), it has to refund the guest with interest. There is also a duty on the hotel to compensate the guest for the costs incurred because of the hotel's breach of contract. The hotel will not be liable where the shortage was beyond its control and they had taken steps to inform the guest accordingly.

The right to disclosure and information: Newton (2010: 745) notes that there may be terms in a contract which are onerous and which are written in fine print in language that is incomprehensible, bearing in mind the low literacy levels of most South Africans. The CPA (Section 22) provides that the consumer has a right to information in language that is "plain and understandable". As a result, suppliers are compelled to use "plain language" when drafting contracts (Stoop, 2011; Reddy, 2012: 594). The right to disclosure and information is extremely important in the hotel sector as it deals with written agreements, disclosure of the price of services offered and any goods that are sold, as well as disclosure in respect of product labelling. According to Newman, the literacy levels in South Africa are so low that, in drafting contracts, the business sector has to accept the responsibility to make them more comprehensible for consumers. Section 22(2) describes "plain language" as language that enables an ordinary consumer with average literacy skills and little experience as a consumer of the relevant goods or services, to understand the content of such contract without much effort. In the hotel sector, this would apply not only to contracts but also to the contents of marketing material and websites; written reservation confirmations; deposit and cancellation policies; and any other notice by way of a sign or in writing (Gordon-Davis \& Cumberlege, 2013: 122). Where an agreement, provision or term does not comply with the "plain language" requirement, it may be void and a court may make an order to sever any portion of the contract, or amend it so that it may be lawful (Sections 51(3) and 52(4); Gouws, 2010: 90).

Section 23 deals with the supplier's duty to disclose the price of goods and services and the consumer's right to know the price of goods and services before purchasing them. Knowler (2014) states that the practice by many restaurant owners which requires their waiters to inform guests of the list of daily specials without disclosing the prices or displaying them on a board or menu insert, may in fact violate the provisions of the CPA (Section 23). Section 24 of the Act contains provisions that apply to the labelling of products and trade descriptions. These provisions are directly relevant to hotels and guests, since hotels may use marketing 
materials or provide the guest with brochures, menus, wine lists and any other commercial communication. Hotels must therefore ensure that all product and service descriptions in such marketing material are factual and not in any way misleading. For instance, using the description of "Mountain View" or "Sea View" rooms may entitle the guest to expect such views (Gordon-Davis \& Cumberlege, 2013: 125).

The right to fair and responsible marketing: The provisions relating to the right of the consumer to fair and responsible marketing, aim to ensure that business practices in respect of advertising are fair and they set out general standards relevant to marketing (Reddy, 2012: 595). Section 29 prohibits service providers from marketing goods in a misleading, fraudulent or deceptive way, while Section 30 prohibits "bait marketing". This provision forbids the practice where suppliers advertise services as being available at a specific price but are deceptive or misleading as to the actual availability of those services (Havenga, 2010: 495). In the hotel sector, for instance, if the hotel plans to offer a limited number of rooms at a special rate to the public, they must disclose precisely the number of rooms to which this special rate applies (Gordon-Davis \& Cumberlege, 2013: 126). Section 33 deals with catalogue marketing. Where the contract was not entered into in person and the consumer is not afforded the chance to inspect the goods (including contracts concluded telephonically, by postal order or over the internet), the consumer will have to be provided with certain information, including a copy of the policies relating to reservation, cancellation and pricing. This section protects the guest and prevents the hotel from introducing a condition that the guest was not aware of at the time of making the reservation. The right to fair and responsible marketing protects consumers against misleading marketing, especially with regard to bait marketing, catalogue marketing and loyalty programmes. It requires hotels to be truthful when they advertise or sell their products and services.

The right to fair and honest dealing: The right to fair and honest dealing protects the consumer against unconscionable conduct. There are several provisions in the Act that deal with honest dealings by hotels. These provisions cover statements that are false or misleading, as well as cases of overbooking. In the marketing, supply or negotiation of goods and services, a hotel "must not use physical force against a consumer, coercion, undue influence, pressure, duress or harassment" or unfair tactics (Section 40(1)). Hotels must not convey a false, misleading or deceptive representation concerning any material fact to a consumer (Section 41(3)). This would include all marketing and advertising material, brochures, menus and wine lists. Information on the hotel's websites would also be subject to this provision. In addition, it will also apply to agents that advertise on behalf of the hotel. Although "puffing" (an opinion or judgement not made as a representation) is allowed, an exaggeration could amount to false or misleading marketing. For instance, a description of the location of the hotel as "close to the airport", but which is actually a two-hour drive from the airport, may amount to misleading marketing.

The right to fair, just and reasonable terms and conditions: In terms of contract law, the parties have the freedom to decide on the content of the contract and whether they wish to be bound by the terms set out in such contract. However, prior to the CPA, contracts were one-sided in favour of suppliers, limiting their liability to consumers, and were often unfair, unjust or unreasonable to the consumer. The Act addresses these challenges under three broad categories.

Unfair, unjust or unreasonable terms: According to Section 48, where goods are supplied or services are rendered, the price and the terms must not be unfair, unreasonable or unjust. The marketing of goods and services in an unfair, unjust or unreasonable manner is also prohibited (Naude, 2009: 514-519). If a term, agreement or condition is excessively biased in favour of the supplier or adversely affects the consumer as to be inequitable, it will be regarded as unfair, unreasonable or unjust (Section 48(2)). Where guests are compelled to accept a "no-refunds under any circumstances" policy by the hotel, if they want to make a reservation, this would be unjust and prohibited, as it is excessively one-sided in favour of the hotel. In addition, Section 17, which deals with the guest's right to cancel an advance reservation, specifically provides for circumstances that would warrant a deposit refund.

Notice for disclaimers: Disclaimers generally exclude or limit one of the parties from liability in certain situations. Section 49 relates to disclaimers by hotels and requires them to give notice to the guest of certain terms and conditions and it covers all agreements and disclaimers, whether they are written or take the form of notices or signs. Although the use of disclaimers is not prohibited by the CPA, hotels have to spell out the 
effects of such disclaimers and terms in "plain and understandable" language as described in Section 22 (McGee, 2010: 20). Notice is required for exemption clauses (i.e. those that limit the liability or risk of the supplier); terms that result in the consumer assuming risk or liability; indemnity clauses; and where the consumer acknowledges any fact (Naude, 2009: 508). The consumer must be notified of these terms in a conspicuous way so that it is likely to attract the attention of the "ordinarily alert consumer" (Naude, 2010: 516). It is not sufficient for these exemption clauses to be printed on the reverse side of the contractual document (even if it is in a different font or colour), as most consumers do not even turn over the contract forms. In addition, given the time and effort it would take to read the terms and understand the implications or find someone to negotiate for them or shop around for better terms, such practice would not satisfy the requirement of adequate notice (Naude, 2009: 508). Hence, in pursuance of the "right to fair, just and reasonable terms", hotels have to re-examine their notices and disclaimers to determine if such disclaimers are protected, now that the CPA is in force.

Unfair prohibitions: The fact that a term and condition may be "one-sided" or favours the supplier does not in itself make it unfair. Sharrock (2010: 308) indicates that such term or condition has to be "excessively" in favour of the supplier to be viewed as unfair. Section 51 contains provisions for prohibited transactions, agreements, terms and conditions. Provisions in hotel-guest contracts would not be valid in terms of Section 51 in the following instances: if they defeat the purpose of the Act; if the hotel misleads or deceives the guest or is fraudulent; if they result in the guest waiving his/her rights; or if it exempts the hotel from liability for gross negligence. Other provisions that would be invalid include those that require the guest to forfeit any money which the hotel is not entitled to; or where the guest undertakes to sign in advance any documentation, regardless of whether such documentation is complete or not. Hence, hotels must ensure that such terms and conditions are not included in any agreement as they will be void where they violate these provisions (Section 51(3)).

The right to fair value, good quality and safety: Guests generally do not just look for accommodation and meals in a hotel stay, but rather an experience that encompasses quality and good value, as well as a safe and secure environment. A guest has a right to performance on time and the hotel must give adequate notice of any delays that are unavoidable. In addition, the hotel must render the services in a manner and quality that a guest is "generally entitled to expect" (Section 54(1)). This would be relevant to hotels in so far as it applies to the quality of accommodation, meals, service (which must be in keeping with the hotel star rating) and administrative and support services. If the hotel fails to provide the services as required, then the guest may demand that they "remedy the defect", or refund the price or a reasonable portion thereof (Section 54 (2)).

Section 55 of the Act affords consumers the right to safe, good quality goods, which are in "good working order" and "free of defects". In the hotel industry, this would imply that guests have the right to expect that goods marketed or sold for human consumption, such as food and beverages at a restaurant or any other goods, are safe and of good quality (Gordon-Davis \& Cumberlege, 2013: 132). Hotel managers should also make sure that before a room key is given, everything in that room is in working order and does not pose any risk to the guest. As demonstrated by the judgment in the case of Naidoo v Birchwood Hotel (2012) where a gate on the hotel premises resulted in bodily injuries to the plaintiff, the hotel may incur liability arising from damages or injury to guests. The right to fair value, good quality and safety places a responsibility on hotels to provide quality service and safe goods and service. In addition, it provides for strict liability of suppliers where there is injury or death, or damage to property because of defects in the goods or access to such items (such as hotel rooms and facilities) and improper labelling (Section 62).

The right to hold the supplier accountable: Where the hotel is in possession of a prepaid deposit, membership fees or vouchers, the CPA makes provision for guests to hold the hotel accountable. Apart from walk-in guests, reservations at hotels are usually pre-booked or paid for in advance. According to Section 64 (1), if a consumer agrees or is required to pay a once off fee or a deposit made 25 days or more in advance for a service or access to a service, such amount "remains the property of the consumer until the supplier makes a charge". If the hotel intends to close but has prior committed reservations and has failed to provide a reasonable alternate facility, it has to give 40 business days' notice to the guest and refund the balance of money owing within five days after the closing of the hotel. 
Consumer refunds: Where the goods supplied are unsafe or defective, the consumer has the right to return such goods and claim a refund within a reasonable time (Section 20). This right is applicable to the food and beverage departments of the hotel. Hence, where a guest feels that the meal ordered is unsafe or does not comply with what was ordered, the guest may request a full refund. Furthermore, in the event that the hotel is unable to provide accommodation as a result of overbooking, the guest is entitled to a full refund plus interest (Section 47).

Right of recourse for guests: One of the purposes of the Act is to ensure that consumers have access to an efficient system for redress as a result of disputes (Section 1; Mupangavanhu, 2012: 322). In terms of Section 4 (1), a guest may seek to enforce any provision of the Act or any agreement, or to resolve a dispute with a hotel or other supplier by referring the matter to a tribunal or ombud. Alternatively, if the dispute does not concern a supplier, the guest may lodge a complaint with the National Consumer Commission or resort to alternate dispute resolution. Guests have a further option to take their disputes and grievances to the National Consumer Tribunal. Consumer complaints relating to the CPA may be heard by the Consumer Tribunal, which may impose penalties (criminal sanctions) in respect of prohibited or required conduct. Such penalty may not exceed 10 percent of the respondent's annual turnover during the preceding financial year or R1 000 000, whichever is the greater (Section 112(2)). Where a guest wants to recover payment or claim delivery of goods, a separate civil action has to be instituted.

Duty to comply: Certain provisions in the CPA, including fair marketing; fair and honest dealing; and those protecting a consumer's health and safety, are ethical business practices which are also linked to social responsibility (Kloppers, 2013: 179). Although ethical business practices may suggest that a business organization may choose whether to abide by such practices or not, the CPA makes it clear that such business practices relating to the business-consumer relationship, are mandatory for all businesses providing goods and services (Reddy \& Rampersad, 2012: 7412), including the hotel sector. Section 100 (1) of the CPA states that, where a particular business organisation engages in prohibited conduct, the Commission may issue a compliance notice and fines may be imposed for non-compliance.

Guest awareness of consumer rights: If consumers are unaware of their rights, they will be deprived of them (Knowler, 2013) and they can be exploited. One of the general purposes of the CPA is therefore to promote the social and economic welfare of consumers by "improving consumer awareness" and "encouraging responsible and informed consumer choice and behaviour" (Section 3 (1) (e)). It is the task of the National Consumer Commission to promote public awareness, including awareness amongst hotel guests, of consumer protection matters (Section 96).

\section{Conclusion}

As hotel guests internationally also face many of the challenges mentioned, the lessons from South Africa and the CPA could provide a basis for minimum standards for hotels in other countries, as well as a basis for consumer protection standards which offer the guest, and consumers generally, much wider protection than that offered by the law of contract to parties. An unrestricted marketplace would mean that dominant suppliers would have the upper hand over consumers. The market therefore requires rules which allow free access to consumers and which offers protection to consumers who may be vulnerable to unfair practices. The CPA therefore requires non-discrimination between consumers and the protection of vulnerable consumers. These responsibilities for the business sector can be achieved through procedural fairness primarily by ensuring transparency (Hawthorne, 2012: 369). The CPA has far-reaching consequences for businesses and consumers and stems from the need to protect consumers from previously disadvantaged backgrounds and prevent widespread unfair practices by business. Hawthorne (2012: 370) rightly points out that the CPA has introduced a shift from the freedom-oriented approach to the fairness-based approach. The freedom of parties to choose the terms and conditions applicable to a contract now appears to be a relic of the past since protection in terms of legislation compensates for the weaker negotiating position of the consumer.

Clearly, the CPA has wide-ranging consequences for hotels and guests as well. The Act applies to goods and services "promoted or supplied in South Africa", including the hotel sector. In terms of the definition set out in the Act, "consumers" would include those to whom the hotel has marketed; those who have concluded the 
transaction; and the recipients of goods and services. The CPA must be viewed as a means to develop historically disadvantaged individuals and assist them "to realize their full potential as consumers". The shift to the fairness-based approach is evident from several of the fundamental consumer rights. Firstly, the right to equality, which prohibits unfair discrimination against guests, furthers the purpose of ensuring that human rights are applicable in contractual relationships, particularly with regard to equality and non-discrimination, given the inequality that existed during the apartheid era. However, there are provisions for reasonable grounds for different treatment in certain circumstances. Secondly, the right to privacy makes provision for consumers to restrict unwanted direct marketing by hotels. Thirdly, the right to choose makes provision for the right to select a supplier, as well as a "cooling-off period" after direct marketing and the guest's right to cancel an advance reservation, booking or order. Fourthly, hotels' marketing practices must be "fair and honest". Fifthly, the right to "fair and responsible marketing" prohibits bait marketing and regulates catalogue marketing and direct marketing. Sixthly, the right to fair and honest dealing protects guests from unconscionable conduct and false and misleading representation of a material fact. With regard to common practices that could be detrimental to guests, such as overbooking and waiver of the right to refunds, the CPA clearly spells out the rights and protection of the guest. Lastly, the right to fair, just and reasonable terms and conditions protects guests form unfair and unreasonable terms and conditions.

As mentioned earlier, the extent to which the CPA can ensure substantive and procedural fairness through transparency is evident from several of its provisions. In view of the social inequality (particularly the high levels of poverty and illiteracy) that stemmed from apartheid and discriminatory laws of the past, the CPA insists on businesses ensuring that their contracts, terms and conditions, and promotional material, are in plain and understandable language. In the past, it was adequate if businesses merely complied with the law by getting the consumer to sign pre-printed forms without explaining their content. Now the emphasis is not merely on compliance but on communicating the essence of the content, i.e. whether the consumer is aware of his/her rights. Hotels must also disclose the prices of goods and services, and ensure that their product labelling and trade descriptions are true and not misleading. Furthermore, the right to "fair, just and reasonable terms" also imposes the duty of explicit notices to guests prior to the agreement, particularly to make them aware of cancellation policies; as well as exemption and indemnity clauses; and the assumption of risk. It further provides for strict liability of hotels in the event of injury, damage to property and death. One of the purposes of the Act is to "improve consumer awareness" (Section 3(1) (e)). It is the responsibility of the Consumer Commission to promote public awareness in consumer protection matters. In addition, the effective enforcement of consumer rights could contribute to forcing organisations into adopting "adequate standards" (Devenney \& Kenny, 2012: 63). This means that if hotels implement the CPA as part of their standard operating procedures, they could ensure that they will not be infringing any consumer rights. The CPA promotes ethical business practices, and it is mandatory for hotels to abide by the CPA. Failure to comply will lead to stringent penalties. An increased awareness of consumer rights and procedures may assist in ensuring greater protection for hotel guests and in ensuring that they receive a better quality of service.

\section{References}

Barth, S. C. (2006). Hospitality Law: Managing Legal Issues in the Hospitality Industry. New Jersey: John Wiley \& Sons Inc.

Ben-Shahar, 0. (2009). The Myth of Opportunity to Read in Contract Law. European Review of Contract Law, $5(1), 1-28$.

Booysen, J. (2011). Consumers Cry for Help. Cape Argus (Online), April 12. Available at: http://www.iol.co.za/capeargus/consumers-cry-for-help-.1055619\#.VIa1oNKUdbE (Accessed: 24 April 2016).

Brink v Kitshoff. (1996). South African Law Reports, 1996(4), 197 (CC).

Carvell, S. A. \& Quan, D. C. (2008). Exotic Reservations - Low Price Guarantees. International Journal of Hospitality Management, 27(2), 162-169.

Chen, C., Shwartz, Z. \& Vargas, P. (2011). The Search for the Best Deal: How Hotel Cancellation Policies Affect the Search and Booking Decisions of Deal-Seeking Customers. International Journal of Hospitality Management, 30, 129-135.

Darcy, S. (2010). Inherent Complexity: Disability, Accessible Tourism and Accommodation Information Preferences. Tourism Management, 31, 816-826. 
Davis, B., Lockwood, A., Alcott, P. \& Pantelidis, I. (2012). Food and Beverage Management. Oxon: Routledge.

Devenney, J. \& Kenny, M. (2012). European Consumer Protection: Theory and Practice. New York: Cambridge University Press.

Geissler, M. L. (2004). Bulk Unsolicited Electronic messages (SPAM): A South African perspective. LLD dissertation. UNISA.

Gladwin, C. \& Civin, A. (2014). The Consumer Protection Act: Direct Marketing. De Rebus, 547, 13.

Gordon-Davis, L. \& Cumberlege, P. 2013. The Hospitality Industry Handbook on Legal Requirements for Hospitality Businesses. 3ed. Claremont: Juta \& Co.

Gough, B., Gough, J. \& du Toit, T. (2008). Hospitality Generics. Pinelands: Pearson Education South Africa.

Gouws, M. (2010). A Consumer's Right to Disclosure and Information: Comments on the Plain Language Provisions of the Consumer Protection Act. South African Mercantile Law Journal, 22, 79-94.

Guillet, B. D., Lui, W. \& Law, R. (2014). Can Setting Hotel Rate Restrictions Help Balance the Interest of Hotels and Customers? International Journal of Contemporary Hospitality Management, 26(6), 948-973.

Guth, S. (2011). Hotel Contract Negotiation: Tips, Tricks and Traps. Virginia: Guth Ventures LLC.

Hamann, B. \& Papadopoules, S. (2014). Direct Marketing and Spam via Electronic Communications: An Analysis of the Regulatory Framework of South Africa. De Jure, 47(1), 42-62.

Havenga, P. (2010). General Principles of Commercial Law. Claremont: Juta.

Hawthorne, L. (2012). Public governance: Unpacking the Consumer Protection Act 68 of 2008. Journal of Contemporary Roman-Dutch Law, 75, 345-370.

Ivanov, S. (2014). Hotel Revenue Management: From Theory to Practice. Varna: Zangador Ltd.

Jacobs, W., Stoop, P. N. \& van Niekerk, R. (2010). Fundamental Consumer Rights under the Consumer Protection Act 68 of 2008: A critical overview and analysis. Potchefstroom Electronic Law Journal, 13(3), 302- 406.

Jennings, M. (2012). Business: Its Legal, Ethical and Global Environment. 10 ed. USA: Cengage Learning.

Kloppers, H. J. (2013). Driving Corporate Social Responsibility (CSR) through the Companies Act: An Overview of the Role of the Social and Ethics Committee. Potchefstroom Electronic Law Journal, 16(1), 166-199.

Knowler, W. (2013). Consumers Must Know Their Rights. The Star (online), January 2. Available: http://www.iol.co.za/news/south-africa/consumers-must-know-their-rights1.1447017\#.VPbn2nyUdbE (Date Accessed: 24 April 2016).

Knowler, W. (2014). Ask the Awkward Questions about Price (online). Available: http://www.iol.co.za/blogs/wendy-knowler-s-consumer-watch-1.1608/ask-the-awkwardquestions-about-price-1.1738154\#.VOMZ1uaUdbG(Date Accessed: 24 April 2016).

Lane, P. (2005). South Africa's equality courts: An early assessment. Race and Transition Series. 22-23. Available at: http://www.csvr.org.za/wits/papers/paprctp5.htm (Date accessed: 16 April 2016).

Layton, A., Robinson, T. \& Tucker, I. B. (2012). Economics for Today. 4 ed. Australia: Cengage Learning.

Marumoagae, M. C. (2012). Disability Discrimination and the Right of Disabled Persons to Access the Labour Market. Potchefstroom Electronic Law Journal, 15(1), 345-428.

Marus, L. (2011). CPA and Plain Language: A not-so-likely threesome. Inside Mining, 4(3), 36-37.

McGee, C. (2010). Will your disclaimer be enforceable under the new Consumer Protection Act? Professional Accountant, Aug/Sept, 20.

Mupangavanhu, Y. (2012). An Analysis of the Dispute Settlement Mechanism under the Consumer Protection Act 68 of 2008. Potchefstroom Electronic Law Journal, 15(5), 320-346.

Naidoo v Birchwood Hotel. (2012). South Africa Law Reports 2012(6), 170 (GSJ).

Naude, T. (2009). The Consumer's Right to Fair, Reasonable and Just Terms under the new Consumer Protection Act in Comparative Perspective. South African Law Journal, 126(3), 505-536.

Naude, T. (2010). Enforcement Procedures in Respect of the Consumer's Right to Fair, Reasonable and Just Contract Terms under the Consumer Protection Act in Comparative Perspective. South African Law Journal, 127(3), 515-547.

Newman, S. (2010). The Influence of Plain Language and Structure on Readability of Contracts. Obiter, 31(3), 734-745.

Noone, B. M. \& Lee, C. H. (2011). Hotel Overbooking: The Effect of Overcompensation on Customers' Reactions to Denied Service. Journal of Hospitality and Tourism Research, 35(3) 334-357.

Okumus, F. (2010). Strategic Management in the International Hospitality and Tourism Industry. Oxford: Butterworth-Heinemann. 
Reddy, K. (2006). The Horizontal Application of the Equality Guarantees and Race Discrimination by the Business Sector. Journal of South African Law, 4, 783,802.

Reddy, K. (2012). Students as Consumers: The Implications of the Consumer Protection Act for Higher Education Institutions in South Africa. South African Journal of Higher Education, 26(3), 586-605.

Reddy, K. \& Rampersad, R. (2012). Ethical Business Practices: The Consumer Protection Act and socioeconomic transformation in South Africa. African Journal of Business Management, 6(25), 7403-7413.

RSA. Republic of South Africa. (1996). Constitution of the Republic of South Africa Act No. 108 of 1996. Pretoria, South Africa: Government Printer.

RSA. Republic of South Africa. (2008). Consumer Protection Act, No. 68 of 2008. Pretoria, South Africa: Government Printer.

Ruzevicius, J. (2012). Products Quality Religious - Ethical Requirements and Certification. Economics and Management, 17(2), 761-767.

Sharrock, R. (2011). Business Transactions Law. 8 ed. Claremont: Juta \& Co. Ltd.

Sharrock, R. D. (2010). Judicial Control of Unfair Contract Terms: The Implications of Consumer Protection Act. South African Mercantile Law Journal, 22 (3), 295-325.

Stoop, P. N. (2011). Plain Language and Assessment of Plain Language. International Journal of Private Law, $4(3), 329-341$.

Tait, M. \& Tait, M. (2010). Equality, The Consumer Protection Act and Customer-segment Pricing Strategies: Is There Relief for the Poor Rich Tourist? Obiter, 31(2), 434-445.

Wilson, R. (2007). Internet Hotel Reservations: The Terms and Conditions Trap. Cornell Hospitality Quarterly, 48(4), 361-369.

Woker, T. (2010). Why the Need for Consumer Protection Legislation? A Look at Some of the Reasons behind the Promulgation of the National Credit Act and the Consumer Protection Act. Obiter, 31(2), 217-231.

Yu, L. (2012). The International Hospitality Business: Management and Operations. New York: The Haworth Hospitality Press.

Zakhary, A., Atiya, A. F., El-Shishiny, H. \& Gayar, N. E. (2011). Forecasting Hotel Arrivals and Occupancy Using Monte Carlo Simulation. Journal of Revenue and Pricing Management, 10, 344-366. 